\title{
A Murine Model of Phosphate Nephropathy
}

\author{
Philipp Eller, ${ }^{\star \dagger}$ Kathrin Eller, ${ }^{\ddagger \S}$ \\ Alexander H. Kirsch, ${ }^{\ddagger}$ Josef J. Patsch, ${ }^{*}$ \\ Anna M. Wolf," Andrea Tagwerker, ${ }^{\ddagger}$ \\ Ursula Stanzl, ${ }^{*}$ Reinhard Kaindl, \\ Volker Kahlenberg," Gert Mayer," \\ Josef R. Patsch, ${ }^{*}$ and Alexander R. Rosenkranz ${ }^{\ddagger \S}$ \\ From the Departments of Internal Medicine I* and Internal \\ Medicine $I V$, and the Tyrolean Cancer Research Institute, "I \\ Innsbruck Medical University, Innsbruck; the Institute of \\ Mineralogy and Petrography," Innsbruck University, Innsbruck; \\ and the Divisions of Angiology, ${ }^{\dagger}$ and Nephrology and \\ Hemodialysis, ${ }^{\circledR}$ Department of Internal Medicine, Graz Medical \\ University, Graz, Austria
}

We established a murine model of phosphate nephropathy with secondary hyperparathyroidism. $\mathrm{db} / \mathrm{db}$ mice, which develop obesity and type 2 diabetes mellitus, were uninephrectomized at the age of 6 weeks and were fed either standard chow or a phosphorus-rich diet during the next 8 weeks. Thereafter, renal cryosections showed abundant tubular casts with a strong histochemical von Kossa reaction in all $\mathrm{db} / \mathrm{db}$ mice on the phosphorus-rich diet but none in the controls. X-ray diffraction and Raman spectroscopy proved that these tubular casts consist mostly of hydroxyapatite $\mathrm{Ca}_{5}\left(\mathrm{PO}_{4}\right)_{3}(\mathrm{OH})$. These intraluminal precipitations were located in distal tubuli and collecting ducts and were associated with degenerative tubular changes and peritubular infiltration of $\mathbf{T}$ cells and macrophages. In line, kidneys of $\mathrm{db} / \mathrm{db}$ mice on the phosphorus-rich diet displayed significantly increased mRNA expression of the $T_{\mathbf{H}} 1$ cytokines interferon $\gamma, \mathrm{IL}-6$, and tumor necrosis factor $\alpha$. In addition, mice developed signs of secondary hyperparathyroidism as shown by elevated serum phosphate, decreased serum calcium, and increased parathyroid hormone, osteopontin, and fibroblast growth factor 23 levels. $\mathrm{db} / \mathrm{db}$ mice on the phosphorus-rich diet also presented with significantly lower body weight, lower homeostasis model assessment of insulin resistance index, and hypertrophic cardiomyopathy. Thus, we provide a murine model of phosphate nephropathy and secondary hyperparathyroidism, which can be used for future pharmacologic and pathophysiologic studies to analyze the effect of hyperphosphatemia on renal, metabolic, and cardiovas- cular phenotypes. (Am J Pathol 2011, 178:1999-2006; DOI: 10.1016/j.ajpath.2011.01.024)

Inorganic phosphorus is essential for multiple biological functions, such as intracellular signal transduction, the production and function of cell membranes, and energy exchange. Although more than $80 \%$ of total body phosphorus is stored in bone and teeth, phosphorus is also found in the intracellular compartment and in serum (primarily in the form of anions such as $\mathrm{H}_{2} \mathrm{PO}_{4}^{-}$and $\mathrm{HPO}_{4}^{2-}$, which are commonly referred to as phosphate). In the steady state, serum phosphate levels are maintained within the physiological range by regulation of dietary absorption, bone formation, bone resorption, and by renal excretion. In the presence of a normal kidney function, renal excretion of excess phosphate is primarily responsible for maintaining phosphate balance. This regulation relies on the inhibition of the tubular sodium phosphate cotransporters and on increased levels of fibroblast growth factor 23 (FGF23) and parathyroid hormone. ${ }^{1-4}$

Hyperphosphatemia occurs whenever the amount of phosphate in the extracellular space exceeds the renal capacity for excretion. Hyperphosphatemia is, thus, a nearly universal complication of advanced renal failure. Large observational studies have also shown a graded association between levels of serum phosphate and allcause mortality in patients with chronic renal failure. The positive phosphate balance seems to cause an accelerated progression of vascular calcification. ${ }^{5-8}$

An acute phosphate load that overwhelms renal capacity for excretion can be derived from endogenous and exogenous sources. Large amounts of endogenous phosphates are released from intracellular stores in tumor lysis syndrome, rhabdomyolysis, and lactic acidosis. Acute hyperphosphatemia can also result from ingestion of excessive amounts of phosphate-containing laxatives and enemas administered for colonoscopy preparation. ${ }^{9}$ Both endogenous and exogenous phosphate loads can

\footnotetext{
Supported by Austrian Research Funds (P21402 to A.R.R.).

P.E. and K.E. contributed equally to the manuscript.

Accepted for publication January 7, 2011

Address reprint requests to Philipp Eller, M.D., Department of Internal Medicine I, Innsbruck Medical University, Anichstrasse 35, 6020 Innsbruck, Austria. E-mail: philipp.eller@i-med.ac.at.
} 
lead to phosphate nephropathy. ${ }^{10-15}$ Acute phosphate nephropathy is a clinical pathologic entity characterized by acute and subsequent chronic renal failure due to tubular precipitation of calcium phosphate deposits forming crystals of hydroxyapatite. ${ }^{16}$ It often followed exposure to oral sodium phosphate bowel purgatives, which were withdrawn from the market in December 2008 after a respective warning from the US Food and Drug Administration. Inadequate hydration and chronic kidney disease are established risk factors for acute phosphate nephropathy. ${ }^{16}$ Most of our present information on phosphate nephropathy derives from case series and retrospective epidemiologic analyses. ${ }^{11,14,17-19}$ Moreover, there is no specific therapy for established phosphate nephropathy.

To study hyperphosphatemia and its renal, metabolic, and cardiovascular complications in more detail, we established and present herein a new animal model for phosphate nephropathy with established secondary hyperparathyroidism.

\section{Materials and Methods}

\section{Study Design}

Five-week-old, male, $\mathrm{db} / \mathrm{db}$, leptin receptor-deficient mice (BKS.Cg-Dock $7^{m}+/+$ Lepr $\left.{ }^{d b} / J\right)$ and male C57BL/6J control mice were obtained from Charles River (Sulzfeld, Germany). The animals were maintained in a virus/antibody-free central animal facility of the Innsbruck Medical University, underwent an uninephrectomy at 6 weeks of age, and were afterward fed either standard chow or a phosphorus-rich diet (Altromin, Lage, Germany), respectively. The phosphorus-rich diet contained $20.46 \mathrm{~g} / \mathrm{kg}$ of phosphorus. The $\mathrm{db} / \mathrm{db}$ mice ate on average $1.6 \mathrm{~g}$ of chow per day and therefore ingested $1 \mathrm{~g} / \mathrm{kg}$ of phosphorus per day. The oral daily dosage of phosphorus in our experimental design was similarly potent to Fleet's phospho-soda used for bowel cleansing in humans (ie, 0.5 $\mathrm{g} / \mathrm{kg}$ of phosphate per day). The phosphorus-rich diet also contained $500 \mathrm{IU} / \mathrm{kg}$ of vitamin $D_{3}, 11.23 \mathrm{~g} / \mathrm{kg}$ of calcium, and $175.88 \mathrm{~g} / \mathrm{kg}$ of crude protein. Body weight, fasting glucose levels, and urinary albumin excretion were measured regularly once a week. The 24-hour urine samples were collected in metabolic cages. Animals were sacrificed at the age of 15 weeks. All animal experiments were approved by Austrian veterinary authorities.

\section{X-Ray Diffraction and Raman Spectroscopy}

$X$-ray diffraction data of the polycrystalline material were collected on a Siemens D5000 powder diffractometer in Bragg-Brentano geometry in the range of $3^{\circ}$ to $70^{\circ} 2 \theta$ $\left(\mathrm{Cu}-\mathrm{K}_{\alpha}\right.$ radiation, parallel beam optics, scintillation counter, generator settings: $40 \mathrm{kV} / 40 \mathrm{~mA}$, step size: $0.01^{\circ} 2 \theta$, counting time per step: 3 seconds). Raman spectra of the aggregate were obtained in the spectral range of 100 to $1200 \mathrm{~cm}^{-1}$ by a Horiba LabRam-HR 800 confocal Raman microspectrometer. The sample was excited by the 532-nm emission line of a 30-mW neodymium:yttriumaluminum-garnet laser under a $100 \times$ objective with a numerical aperture of 0.9 . The size and power of the laser spot on the sample were approximately $1 \mu \mathrm{m}$ and 0.5 $\mathrm{mW}$, respectively. The scattered light was dispersed by a grating with $1800-\mathrm{mm}^{-1}$ lines and collected by a $1024 \times$ 256-pixel open electrode charged-coupled device detector. The spectral resolution, determined by measuring the Rayleigh line, was approximately $1.4 \mathrm{~cm}^{-1}$. Background was subtracted by fitting a polynomial function of third order to the spectrum. The wave number accuracy of approximately $0.5 \mathrm{~cm}^{-1}$ was achieved by adjusting the zero-order position of the grating and checked by a neon spectral calibration lamp. The measured spectra were loaded into the software Spectral-ID by Galactic and compared with database spectra supplied by Horiba.

\section{Metabolic Studies}

Blood glucose levels were measured using OneTouch Ultra2 (Lifescan, Vienna, Austria), urine creatinine was quantified spectrophotometrically using a picric acidbased method (Sigma, St. Louis, MO), and urinary albumin was determined by a double-sandwich enzymelinked immunosorbent assay (Abcam, Cambridge, MA) as reported previously. ${ }^{20}$ Serum urea, serum calcium, and serum phosphate levels were measured with standard laboratory techniques. The glucose tolerance test was performed at the age of 7 weeks and the insulin tolerance test at the age of 15 weeks. For the glucose tolerance test, we administered glucose $(1.0 \mathrm{~g} / \mathrm{kg})$ by intraperitoneal injection after an overnight fast and measured blood glucose levels before and 15, 30, 60, and 120 minutes after glucose application. For the insulin tolerance test, we injected $0.75 \mathrm{U} / \mathrm{kg}$ of human insulin aspart (Novo Nordisk, Sorgenfri, Denmark) and measured the blood glucose level before and $15,30,45,60$, 75 , and 90 minutes after insulin application. At the age of 15 weeks, we also measured fasting insulin levels (Crystal Chem, Downers Grove, IL), serum FGF23 levels (Kainos Laboratories Inc., Tokyo, Japan), serum osteopontin levels (R\&D Systems, Minneapolis, MN), and intact parathyroid hormone levels (ALPCO, Salem, NH) by enzyme-linked immunosorbent assay. The homeostasis model assessment of insulin resistance (HOMA-IR) was calculated by use of the glucose-insulin product divided by the constant 22.5. ${ }^{21-22}$ Furthermore, we measured the fat cell diameter in subcutaneous and visceral (epididymal) adipose tissue at a magnification of 100 using a ProgRes C12 camera and the ProgRes Capture Pro 2.5 software with the straight line tool (Jenoptik GmbH, Jena, Germany). At least 200 adipocytes from both subcutaneous and visceral adipose tissue were evaluated for each mouse in a blinded fashion.

\section{Renal Staining}

Renal cryosections were targeted with 1\% silver nitrate solution (Sigma). The argentaffin reaction described by von Kossa is photochemical in nature where the activation energy is supplied by UV light. ${ }^{23}$ The calcium ions were reduced by the UV light and replaced by silver ions reacting with the phosphate deposits. Thus, these phos- 


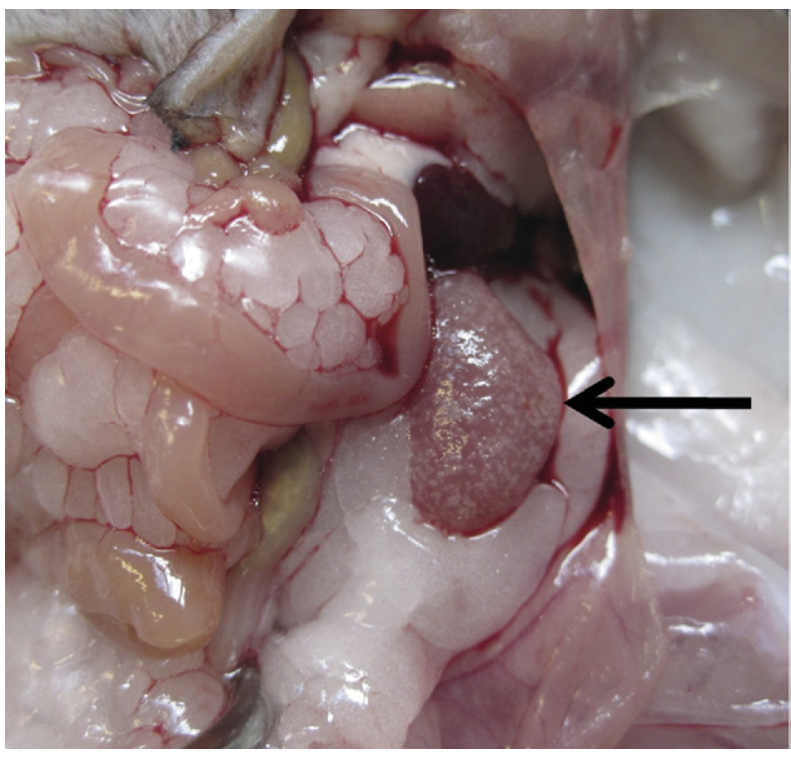

Figure 1. Exploratory laparotomy in mice with phosphate nephropathy. Multiple white granular deposits beneath the renal fascia were evident by macroscopic inspection of the kidneys in mice on the phosphorus-rich diet The black arrow indicates the position of the single kidney in the abdomen.

phate deposits are visualized by the metallic silver. The cryosections were counterstained with nuclear fast red (Sigma). Formalin-fixed renal tissue was embedded in paraffin, cut in 4- $\mu \mathrm{m}$ sections, and stained with acid fuchsin and orange $G$ using standard staining techniques. To determine the nephron segments that contained the inorganic precipitations, the renal specimens were stained with lectins of Arachis hypogaea and Dolichos biflorus (Sigma), which are markers of distal tubuli and collecting ducts, as shown by Markowitz et al. ${ }^{13}$ Briefly, deparaffinized tissue sections were treated by autoclave for 7 minutes at $121^{\circ} \mathrm{C}$ in target retrieval solution (Dako, Glostrup, Denmark), quenched in $0.3 \% \mathrm{H}_{2} \mathrm{O}_{2}$ in methanol, blocked with biotin/avidin blocking kit (Vector Laboratories Inc., Burlingame, CA), and then overlaid with biotin-conjugated $A$. hypogaea and $D$. biflorus, each at a concentration of $0.01 \mathrm{mg} / \mathrm{mL}$, for 50 minutes at room temperature. Color reactions were developed with aminoethylcarbazol after incubation with extravidin-peroxidase (Sigma).

The three-layer immunoperoxidase technique on frozen tissue sections ( $4 \mu \mathrm{m}$ ) was used for the detection of macrophages and T cells in the kidney sections. Macrophages were stained using the rat anti-mouse F4/80 and CD68 antibody (Serotec, Oxford, England). A semiquantitative scoring system was performed as follows: 0,0 to 4 cells stained positive; $1+, 5$ to 10 cells; $2+, 10$ to 50 cells; $3+, 50$ to 200 cells; and $4+$, more than 200 cells stained positive per low-power field. For the detection of $\mathrm{CD}^{+}{ }^{+}$and $\mathrm{CD}^{+}{ }^{+} \mathrm{T}$ cells, rat anti-mouse CD4 and CD $8 \alpha$ monoclonal antibodies (Serotec) were used, respectively. Biotin-conjugated goat anti-rat IgG antibody (Jackson ImmunoResearch Laboratories, West Grove, PA) was used as a secondary antibody, followed by incubation with an avidin-biotin complex and subsequent development with $0.4 \%$ 3-amino-9-ethylcarbazole for 6 minutes and counterstaining with Gill's Hematoxylin No. 3 (Polysciences, Warrington, PA). Quantification of T cells was performed by counting the number of cells in six adjacent high-power fields of renal cortex and medulla.

\section{Cardiovascular Studies}

After sacrifice, mice were perfused transcardially with phosphate-buffered saline. Transverse sections of the perfused hearts were next fixed in formalin and scanned by Epson 3170 Photo (Seiko Epson, Nagano, Japan). The left ventricular dimension, posterior wall thickness, and septal wall thickness were measured in a blinded fashion according to the American Society of Echocardiography guidelines. $^{24}$
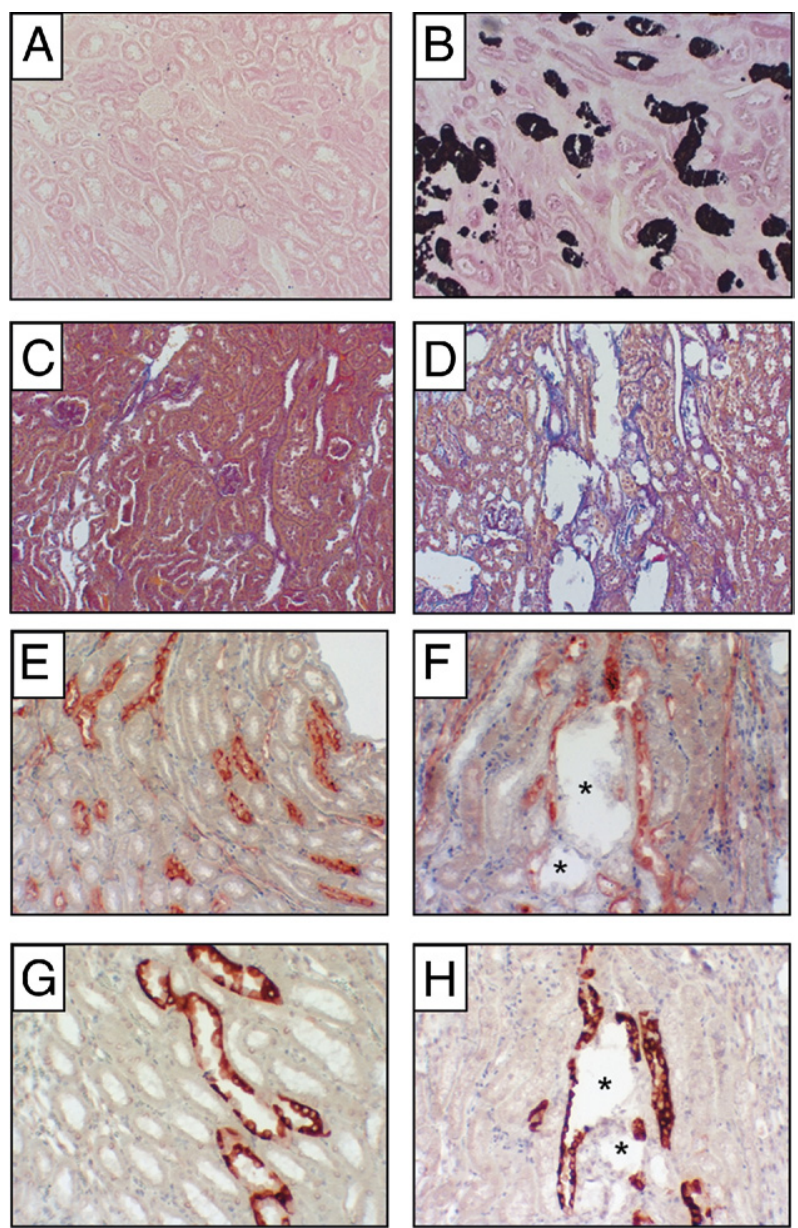

Figure 2. Histologic verification of phosphate nephropathy. There was not a single deposit with a positive von Kossa stain in the control $\mathrm{db} / \mathrm{db}$ mice fed standard chow (A), whereas renal cryosections revealed abundant tubular calcium phosphate deposits with a positive histochemical von Kossa reaction in $\mathrm{db} / \mathrm{db}$ mice fed the phosphorus-rich diet (B). Kidney-sections of $\mathrm{db} / \mathrm{db}$ mice fed the phosphorus-rich diet were also stained with acid fuchsin and orange $\mathrm{G}$ and showed degenerative tubular changes with concomitant fibrosis (D), which were absent in $\mathrm{db} / \mathrm{db}$ mice fed standard chow (C). Lectin staining with $A$. hypogaea $(\mathbf{E}$ and $\mathbf{F})$ and D. biflorus $(\mathbf{G}$ and $\mathbf{H})$ showed no calcifications in distal tubuli $(\mathbf{E})$ and collecting ducts $(\mathbf{G})$ of controls, whereas calcifications (asterisks) were located to the distal tubuli (F) and collecting ducts $(\mathbf{H})$ of $\mathrm{db} / \mathrm{db}$ mice on the phosphorus-rich diet. Representative pictures are shown with a magnification of $100 \times(\mathbf{A}-\mathbf{D})$ and $200 \times(\mathbf{E}-\mathbf{H})$, respectively. 


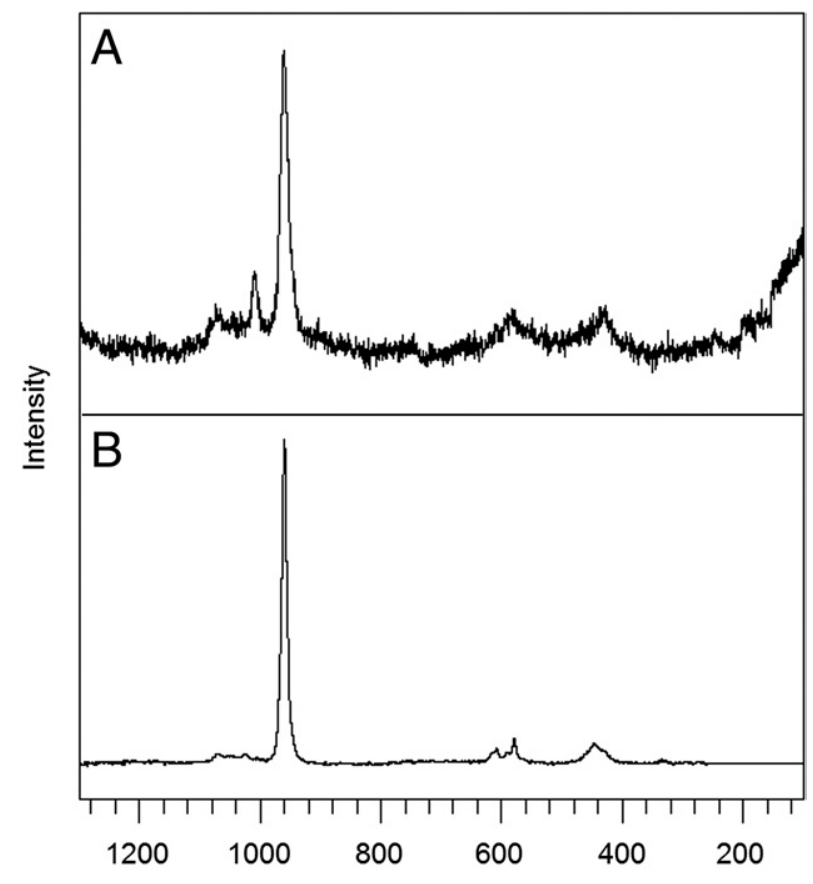

Raman Shift $\left[\mathrm{cm}^{-1}\right]$

Figure 3. Raman spectroscopy of renal precipitations in phosphate nephropathy. The Raman spectrum of the murine tubular aggregates (A) showed an intense, sharp band at $961 \mathrm{~cm}^{-1}$ and several other weaker bands, which are typical for submicrocrystalline hydroxyapatite $\mathrm{Ca}_{5}\left(\mathrm{PO}_{4}\right)_{3}(\mathrm{OH})$ in biological tissues. At the bottom, there is the reference Raman spectrum of human tooth $(\mathbf{B})$

\section{Reverse Transcription and Real-Time PCR}

Total RNA was isolated from kidneys using Trizol (Sigma) according to a standard protocol. Thereafter, $2 \mu \mathrm{g}$ of total RNA was reverse transcribed using a Superscript III Transcription Kit (Nitrogen, Carlsbad, CA) and random primers (Roche, Basel, Switzerland). Real-time PCR was performed on an ABI Prism 7700 (Applied Biosystems, Foster City, CA). For linear amplification of FoxP3 and tumor necrosis factor $\alpha$ (TNF- $\alpha$ ), SYBR Green Master Mix (Nitrogen) and the following primers were used: FoxP3 forward 5'-TCTTGCCAAGCTGGAAGACT-3' and reverse 5'-AGCTGATGCATGAAGTGTGG-3' and TNF- $\alpha$ forward 5'-GAACTGGCAGAAGAGGCACT-3' and reverse 5'AGGGTCTGGGCCATAGAACT-3' ${ }^{25}$ For quantification of IL-6, IFN- $\gamma$, Gata-3, IL-10, and IL-17, Taqman Master mix (Applied Biosystems) and the gene expression assays Mm00446190_m1, Mm00901778_m1, Mm00484683_m1, Mm00439616_m1, and Mm00439619_m1 (Applied Biosystems) were used. $18 \mathrm{~S}$ served as the reference gene.

\section{Statistical Analysis}

Results are presented as mean \pm SEM. Normal distribution of data was assessed by the Kolmogorov-Smirnov test with Lilliefors correction. Both groups were compared by either nonparametric Mann-Whitney U-test or unpaired $t$-test as appropriate, depending on the distribution of the tested variable. A two-tailed $P<0.05$ was considered statistically significant. All statistical analyses were performed with SPSS statistical software version 15.0 for Windows (SPSS Inc., Chicago, IL).

\section{Results}

\section{The Model}

For our animal model, we subjected $\mathrm{db} / \mathrm{db}$, leptin receptor-deficient mice (BKS.Cg-Dock $7^{m}+/+$ Lepr $^{\text {db }} / J$ ) to uninephrectomy to simulate chronic kidney disease at the age of 6 weeks and fed them either a phosphorus-rich diet or standard chow, respectively, for the next 8 weeks. $\mathrm{db} / \mathrm{db}$ mice have hyperphagia, obesity, type 2 diabetes mellitus, polyuria, and, thus, volume depletion, which is another established risk factor for phosphate nephropathy. ${ }^{16}$

\section{Renal Phenotype}

All seven $\mathrm{db} / \mathrm{db}$ mice on the phosphorus-rich diet and none of the eight controls fed standard chow developed
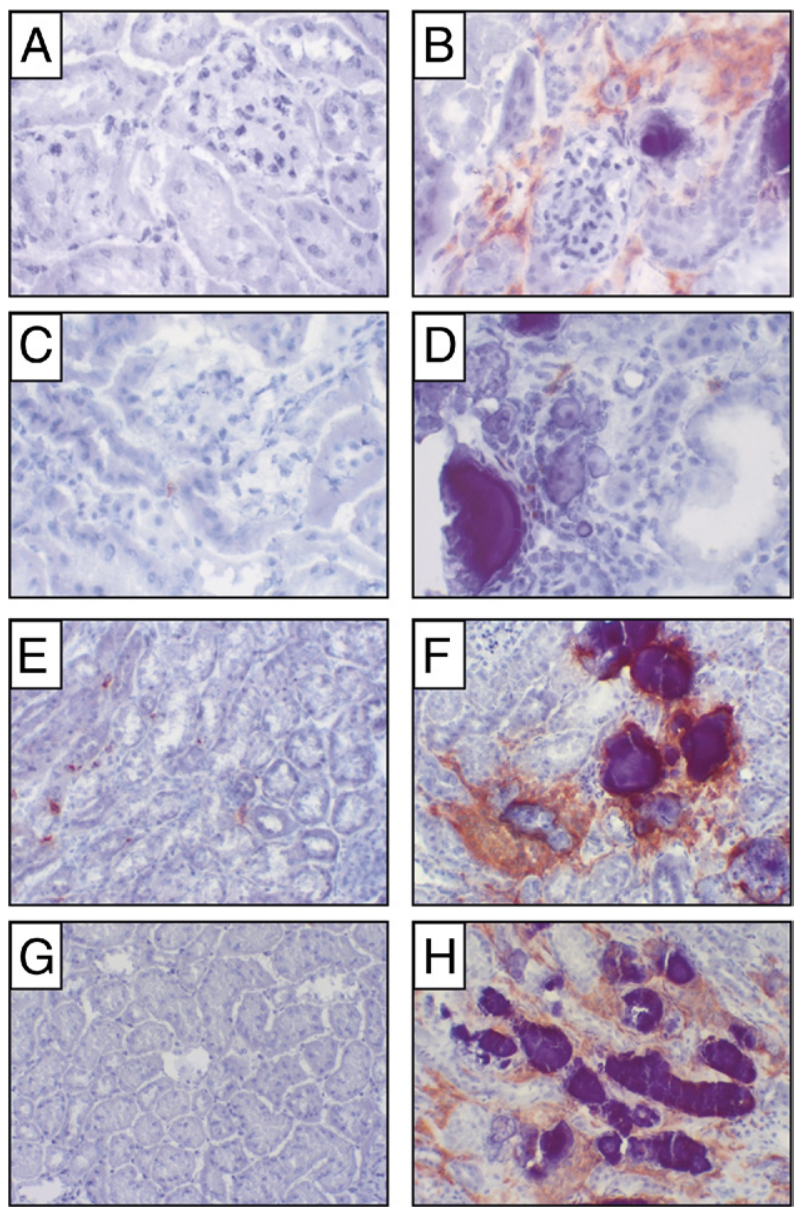

Figure 4. Leukocyte infiltration in phosphate nephropathy. Kidney infiltration of $\mathrm{CD}^{+}{ }^{+} \mathrm{T}$ cells $(\mathbf{A}$ and $\mathbf{B}), \mathrm{CD}^{+} \mathrm{T}$ cells $(\mathbf{C}$ and $\mathbf{D}), \mathrm{CD} 68^{+}$cells $(\mathbf{E}$ and $\mathbf{F})$, and $\mathrm{F} 4 / 80^{+}$cells $(\mathbf{G}$ and $\mathbf{H})$ in controls $(\mathbf{A}, \mathbf{C}, \mathbf{E}$, and $\mathbf{G})$ and mice with phosphate nephropathy $(\mathbf{B}, \mathbf{D}, \mathbf{F}$, and $\mathbf{H})$ are shown. Representative pictures were taken at a magnification $400 \times$ for $\mathrm{T}$ cells $(\mathbf{A}-\mathbf{D})$ and at a magnification of $200 \times$ for macrophages $(\mathbf{E}-\mathbf{H})$. 

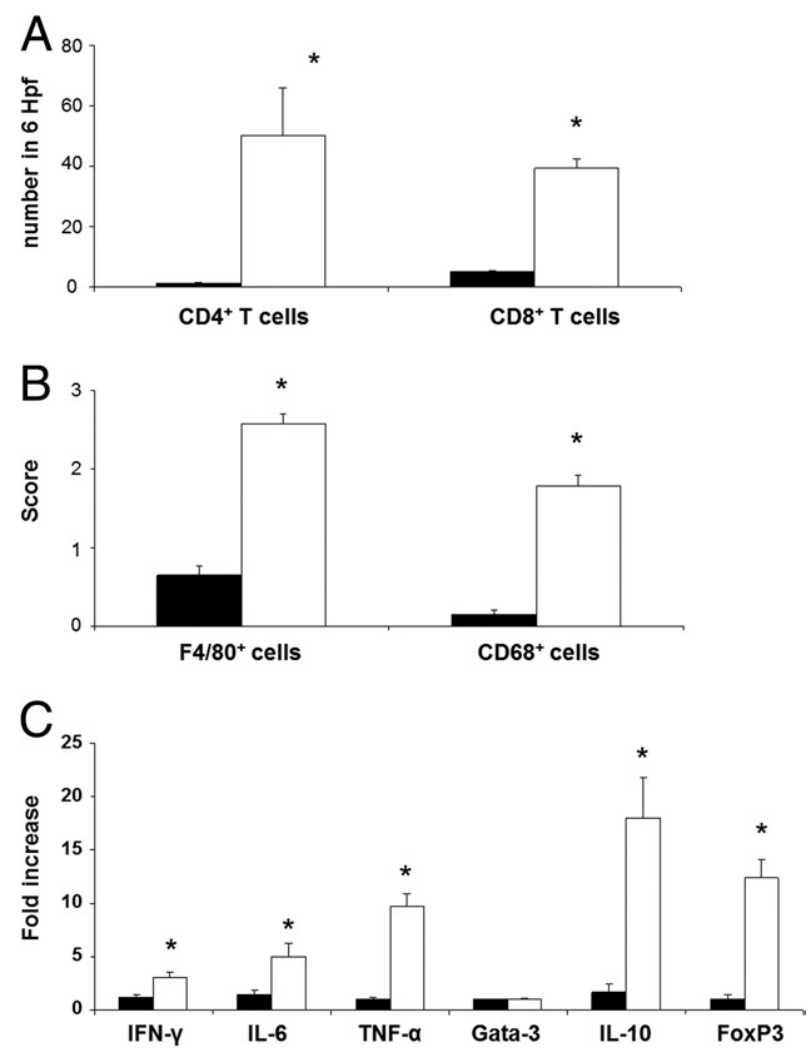

Figure 5. Peritubular infiltration and renal cytokine expression in phosphate nephropathy. Peritubular infiltration of $\mathrm{CD}^{+} \mathrm{T}$ cells, $\mathrm{CD}^{+} \mathrm{T}$ cells $(\mathbf{A})$, and macrophages $(\mathbf{B})$ in phosphate nephropathy (white bars; $n=7$ ) compared with controls (black bars; $n=8$ ). Kidneys of $\mathrm{db} / \mathrm{db}$ on phosphorus-rich diet (white bars; $n=7$ ) displayed significantly increased mRNA expression of the $\mathrm{T}_{\mathrm{H}} 1$ cytokines IFN- $\gamma$, IL- 6 , and TNF- $\alpha$, whereas the master regulator of $\mathrm{T}_{\mathrm{H}} 2$ cells, Gata-3, was comparable to the levels of kidneys of $\mathrm{db} / \mathrm{db}$ mice fed standard chow (black bar; $n=8)(\mathbf{C})$. IL-10 and FoxP3 were found to be significantly increased in kidneys of $\mathrm{db} / \mathrm{db}$ mice fed the phosphorus-rich diet. ${ }^{*} P<0.05$.

phosphate nephropathy. Exploratory laparotomy of mice fed the phosphorus-rich diet showed multiple white granular deposits beneath the renal fascia by macroscopic inspection (Figure 1). There were no such visible deposits in control $\mathrm{db} / \mathrm{db}$ mice fed standard chow. To verify phosphate nephropathy, we next performed histologic analyses looking for tubular hydroxyapatite crystals, which are the pathognomonic hallmark of phosphate nephropathy. The renal cryosections revealed abundant intraluminal tubular deposits of these crystals with a strong histochemical reaction in the von Kossa stain in $\mathrm{db} / \mathrm{db}$ mice on the phosphorus-rich diet (Figure 2B). There was not a single deposit with a positive von Kossa reaction in the $\mathrm{db} / \mathrm{db}$ controls fed standard chow (Figure 2A). Next, we performed X-ray diffraction and Raman spectroscopy of the inorganic extracts from kidneys to analyze the mineral composition of the tubular precipitations. Despite the low crystallinity of the sample, a qualitative phase analysis based on a comparison between the experimental X-ray diffraction data and the entries of the Powder Diffraction File 4 database allowed the identification of an apatite phase $\left[\mathrm{Ca}_{5}\left(\mathrm{PO}_{4}\right)_{3}(\mathrm{OH}, \mathrm{F})\right]$ as the main constituent. Additional lines may point to the simultaneous presence of monetite $\left(\mathrm{CaHPO}_{4}\right)$ as a second phase. These results were in good agreement with the outcome of the spectroscopic investigations. The Raman spectrum of the aggregate showed an intense, sharp band at $961 \mathrm{~cm}^{-1}$, a weaker band at $1010 \mathrm{~cm}^{-1}$, and several broad, weak bands around 420, 600, 780, and $1080 \mathrm{~cm}^{-1}$ (Figure 3). Intensity, full width at half maximum, and wave number of most of these bands, with the exception of the one at $1010 \mathrm{~cm}^{-1}$, are typical for submicrocrystalline hydroxyapatite in biological tissues. The weak band at 1010 $\mathrm{cm}^{-1}$ might be related to subordinately occurring material of an unidentified phase. Thus, X-ray diffraction and Raman spectroscopy showed without doubt that the tubular precipitations in our animal model consisted mostly of hydroxyapatite $\mathrm{Ca}_{5}\left(\mathrm{PO}_{4}\right)_{3}(\mathrm{OH})$ crystals.

These multiple intraluminal deposits of hydroxyapatite were associated with degenerative tubular changes, such as tubular ectasia and simplification, with desquamated apoptotic epithelial cells, diffuse interstitial edema, and fibrosis (Figure 2, C and D). Glomeruli appeared unremarkable. The hydroxyapatite crystals were located in distal tubuli (Figure 2, E and F) and collecting ducts (Figure 2, $\mathrm{G}$ and $\mathrm{H}$ ), as shown by lectin staining using $A$. hypogaea and $D$. biflorus, which are specific markers for

Table 1. Biochemical Parameters in Phosphate Nephropathy

\begin{tabular}{lccc}
\hline & Controls $(n=8)$ & Phosphorus $(n=7)$ & $P$ value \\
\hline Serum phosphate, $\mathrm{mmol} / \mathrm{L}$ & $2.80 \pm 0.12$ & $3.77 \pm 0.77$ & 0.021 \\
Serum calcium, $\mathrm{mmol} / \mathrm{L}$ & $2.31 \pm 0.05$ & $1.97 \pm 0.14$ & 0.050 \\
Serum urea, $\mathrm{mmol} / \mathrm{L}$ & $10.9 \pm 0.3$ & $14.1 \pm 1.6$ & 0.092 \\
Urinary albumin:creatinine ratio & $0.14 \pm 0.02$ & $0.20 \pm 0.06$ & 0.42 \\
Body weight, g & $52.3 \pm 4.2$ & $0.223 \pm 0.1$ & 0.004 \\
Kidney weight, $\mathrm{g}$ & $0.261 \pm 0.010$ & $64.4 \pm 0.8$ & 0.026 \\
Glomerular diameter, $\mu \mathrm{m}$ & $69.0 \pm 0.7$ & $4.9 \pm 0.4$ & $<.0001$ \\
Fasting blood glucose, mmol/L & $19.1 \pm 2.9$ & $1006 \pm 198$ & 0.001 \\
Fasting insulin, pmol/L & $625 \pm 107$ & $33 \pm 9$ & $0.054^{*}$ \\
HOMA insulin resistance & $64 \pm 7$ & $102.2 \pm 0.7$ & 0.021 \\
Visceral adipocyte diameter, $\mu \mathrm{m}$ & $114.7 \pm 0.7$ & $102.8 \pm 0.7$ & $<.0001$ \\
Subcutaneous adipocyte diameter & $103.7 \pm 0.7$ & $1.52 \pm 0.02$ & 0.33 \\
Septal wall thickness, mm & $1.27 \pm 0.06$ & $1.64 \pm 0.09$ & 0.014 \\
Posterior wall thickness, $\mathrm{mm}$ & $1.34 \pm 0.07$ & $5.19 \pm 0.04$ & 0.029 \\
Left ventricular diameter, $\mathrm{mm}$ & $5.01 \pm 0.24$ & & 0.55 \\
\hline
\end{tabular}

*By Mann-Whitney U-test. 

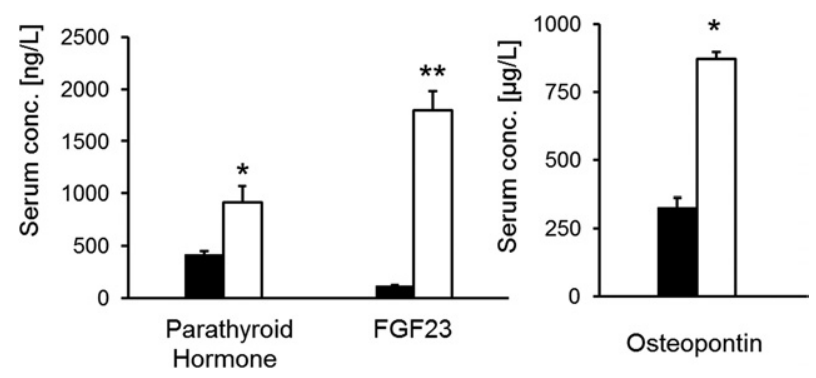

Figure 6. Secondary hyperparathyroidism and FGF23 excess in phosphate nephropathy. $\mathrm{db} / \mathrm{db}$ mice fed the phosphorus-rich diet (white bars; $n=7$ ) had significantly higher serum parathyroid hormone, higher serum FGF23, and higher serum osteopontin levels when compared with $\mathrm{db} / \mathrm{db}$ mice fed standard chow (black bars; $n=8$ ). ${ }^{*} P<0.05$; ${ }^{* *} P<0.005$.

the respective nephron segments. These apatitic precipitations were associated with a prominent renal infiltration of leukocytes (Figures 4 and 5). $\mathrm{CD} 4^{+}$and $\mathrm{CD} 8^{+} \mathrm{T}$ cells were found to infiltrate kidneys of $\mathrm{db} / \mathrm{db}$ mice on the phosphate-rich diet throughout the interstitium (Figure 4, A-D, and Figure 5A). In contrast, most macrophages, stained with CD68 and F4/80, infiltrated into the peritubular regions in close proximity to the tubular hydroxyapatite crystals (Figure 4, E-H, and Figure 5B). In line, kidneys of $\mathrm{db} / \mathrm{db}$ mice on the phosphorus-rich diet displayed significantly increased mRNA expression of the $T_{H} 1$ cytokines IFN- $\gamma$, IL- 6 , and TNF- $\alpha$, whereas the master regulator of $\mathrm{T}_{\mathrm{H}} 2$ cells, Gata-3, was comparable to the levels of kidneys of $\mathrm{db} / \mathrm{db}$ mice fed standard chow (Figure 5C). IL-10 and FoxP3 were found to be significantly increased in kidneys of $\mathrm{db} / \mathrm{db}$ mice on the phosphorus-rich diet (Figure 5C), whereas IL-17 was not detectable (data not shown). Blood sample analyses showed a significant increase of serum phosphate levels and a significant decrease of serum calcium levels in $\mathrm{db} / \mathrm{db}$ mice on the phosphorus-rich diet when compared with $\mathrm{db} / \mathrm{db}$ control mice fed standard chow (Table 1).
These $\mathrm{db} / \mathrm{db}$ mice with phosphate nephropathy displayed also a secondary hyperparathyroidism with significantly elevated serum parathyroid hormone levels that were associated with a secondary FGF23 excess and elevated serum osteopontin levels (Figure 6). At the end of the experiment, both the mean kidney weight and the mean glomerular diameter were significantly higher in the $\mathrm{db} / \mathrm{db}$ control mice when compared with the $\mathrm{db} / \mathrm{db}$ mice on the phosphorus-rich diet (Table 1). There was no significant difference in albuminuria between the two treatment groups (Table 1). Of note, uninephrectomized C57BL/6 mice fed the phosphorus-rich diet did not develop phosphate nephropathy (data not shown).

\section{Metabolic Phenotype}

Mice with phosphate nephropathy had a restrained insulin resistance. $\mathrm{db} / \mathrm{db}$ mice on the phosphorus-rich diet had less body weight (Figure 7A), a significantly lower fasting blood glucose level (Figure 7C), a lower HOMA-IR index, and most importantly smaller adipocyte diameters in the visceral adipose tissue (Table 1). Moreover, the mice on the phosphorus-rich diet also performed better on the glucose tolerance test (Figure 7B) and on the insulin tolerance test when compared with controls (Figure 7D). There was no significant difference in the size of adipocytes in subcutaneous adipose tissue.

\section{Cardiovascular Phenotype}

After 8 weeks of treatment on the phosphorus-rich diet, there was no detectable vascular calcification in the aorta or in the renal vessels in $\mathrm{db} / \mathrm{db}$ mice, which have a C57BL/6 background and are known to be resistant to vascular calcification. ${ }^{26} \mathrm{db} / \mathrm{db}$ mice on the phosphorusrich diet, however, displayed significantly thicker septal and posterior walls of the left ventricle, which are remi-
A
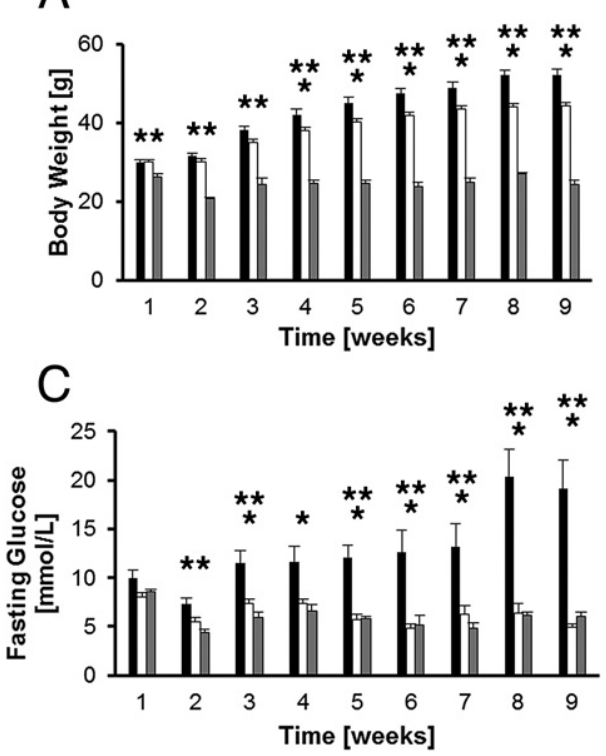
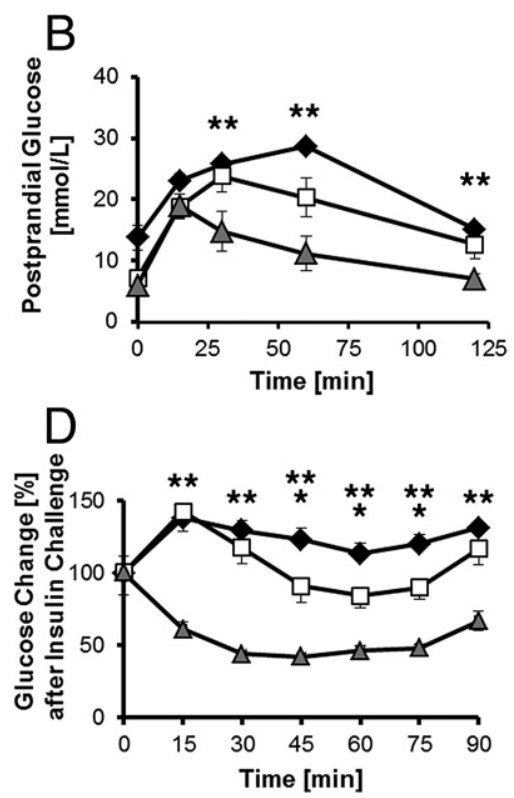

Figure 7. Insulin resistance is restrained by phosphate nephropathy. $\mathrm{db} / \mathrm{db}$ mice fed the phosphorus-rich diet (white bars; $n=7$ ) gained less body weight $(\mathbf{A})$, had lower fasting blood glucose levels (C), and showed a better performance on the glucose tolerance test (B) and the insulin tolerance test $(\mathbf{D})$ when compared with control $\mathrm{db} / \mathrm{db}$ mice (black bars; $n=8$ ). Significant difference of * $P$ value $<0.05$ between the $\mathrm{db} / \mathrm{db}$ mice fed standard chow (black bars/diamonds) and the $\mathrm{db} / \mathrm{db}$ mice fed the phosphorusrich diet (white bars/squares). Significant difference of ${ }^{* * *} P<0.05$ between the $\mathrm{db} / \mathrm{db}$ mice fed standard chow (black bars/diamonds) and the C57Bl6 control mice fed the phosphorus-rich diet (gray bars/triangles; $n=3$ ). 
niscent of hypertrophic cardiomyopathy in end-stage renal failure (Table 1).

\section{Discussion}

This is, to our knowledge, the first report of an animal model of phosphate nephropathy. Up to date, there is no specific treatment for phosphate nephropathy. Therefore, this murine model may serve as a tool to test pharmacologic interventions to counteract and to treat the precipitation of hydroxyapatite crystals in the renal tubuli. The murine model of phosphate nephropathy displayed plenty of tubular aggregates with strong histochemical reaction in the von Kossa stain, which were located to the distal tubuli and collecting ducts. X-ray diffraction and Raman spectroscopy proved these precipitations to be submicrocrystalline hydroxyapatite crystals. The associated tubular degenerative changes and the peritubular infiltration of lymphocytes and macrophages exactly mirror the pathology of biopsy-proven acute phosphate nephropathy in humans. ${ }^{11,14,17,27-33}$

Moreover, the presented animal model has manifold facets of overt hyperphosphatemia and of secondary hyperparathyroidism. Uninephrectomized $\mathrm{db} / \mathrm{db}$ mice on the phosphorus-rich diet displayed not only elevated serum phosphorus and decreased serum calcium levels but also a strong secondary up-regulation of serum FGF23, ${ }^{3}$ serum parathyroid hormone, and serum osteopontin levels. A similar secondary FGF23 excess and secondary hyperparathyroidism were also described in the animal model by El-Abbadi et al, ${ }^{26}$ where uremia was generated first by a two-step surgical procedure for partial renal ablation before application of an oral phosphate overload. In contrast to the model of El-Abbadi et al, our animals did not develop arterial medial calcification in the 8 weeks on the phosphorus-rich diet. This difference is probably due to the different genetic background of the mice used. DBA/2 mice are prone to develop medial calcifications, whereas C57BL/6 mice are resistant to vascular calcifications. Another important difference to the model of El-Abbadi et al is the fact that our mice were not uremic and can thereby serve to study early changes in calcium and phosphorus metabolism in chronic kidney disease. Furthermore, we were able to evaluate the morphologic changes in the kidney due to high oral phosphate load, which is not possible in the renal ablation model of Gallimore et $\mathrm{al}^{34}$ that is induced by sequential electrocoagulation of the right renal cortex and left nephrectomy. A limitation of our model is, in contrast to the typical histologic changes in humans with phosphate nephropathy, the lack of renal fibrosis in our $\mathrm{db} / \mathrm{db}$ mice treated with the phosphorus-rich diet at the evaluated time point.

The uninephrectomized $\mathrm{db} / \mathrm{db}$ mice on the phosphorus-rich diet also had a restrained insulin resistance with a lower HOMA-IR index and smaller visceral adipocytes and developed a concentric left ventricular cardiac hypertrophy. It is not yet clear whether these metabolic and cardiac phenotypes are primary or secondary effects of hyperphosphatemia, secondary hyperparathyroidism, or blood pressure elevation. A limitation of this study may be that the food intake of $\mathrm{db} / \mathrm{db}$ mice on the phosphorus-rich diet on the one hand and standard chow on the other hand was not controlled and normalized. $\mathrm{db} / \mathrm{db}$ mice on the phosphorus-rich diet had a lower body weight, which may be due to less food intake and may explain at least in part the better insulin resistance when compared with mice on a standard diet. However, the reduced weight gain could also be a consequence of impaired kidney function and cardiac hypertrophy. A big advantage of this model of phosphate nephropathy is the fact that it does not rely on genetic defects in the renal phosphate metabolism to produce the renal phenotype, as holds true for mice homozygous for the disrupted type Ila Na/Pi cotransporter gene Npt2, for instance. ${ }^{35}$

Interestingly, kidneys of $\mathrm{db} / \mathrm{db}$ mice on the phosphorus-rich diet displayed a decreased kidney size compared with controls. This difference in kidney size may be due to the different glycemic control and the resulting diabetic nephropathy of the control mice. Alternatively, the different kidney weight could also result from a beginning chronic kidney disease in $\mathrm{db} / \mathrm{db}$ mice with phosphate nephropathy, as indicated by the trend to higher urea levels in these mice on the phosphorus-rich diet.

In conclusion, the present study opens the door for future pharmacologic and pathophysiologic studies that analyze, on the one hand, phosphate nephropathy and, on the other hand, the effect of hyperphosphatemia and secondary hyperparathyroidism on renal, metabolic, and cardiovascular phenotypes. This animal model may, thus, aid the study of the phosphate homeostasis in more detail because it is still associated with adverse clinical outcomes in both acute phosphate nephropathy and chronic renal failure..$^{5,7,8,36-38}$

\section{References}

1. Murer $H$, Lotscher $M$, Kaissling $B$, Levi M, Kempson SA, Biber J: Renal brush border membrane $\mathrm{Na} / \mathrm{Pi}$-cotransport: molecular aspects in PTH-dependent and dietary regulation. Kidney Int 1996, 49:17691773

2. Prie D, Friedlander G: Genetic disorders of renal phosphate transport. N Engl J Med 2010, 362:2399-2409

3. Wolf M: Forging forward with 10 burning questions on FGF23 in kidney disease. J Am Soc Nephrol 2010, 21:1427-1435

4. Prie D, Urena Torres $P$, Friedlander G: Latest findings in phosphate homeostasis. Kidney Int 2009, 75:882-889

5. Foley RN, Collins AJ, Herzog CA, Ishani A, Kalra PA: Serum phosphorus levels associate with coronary atherosclerosis in young adults. J Am Soc Nephrol 2009, 20:397-404

6. Maizel J, Six I, Slama M, Tribouilloy C, Sevestre H, Poirot S, Giummelly P, Atkinson J, Choukroun G, Andrejak M, Kamel S, Maziere JC, Massy ZA: Mechanisms of aortic and cardiac dysfunction in uremic mice with aortic calcification. Circulation 2009, 119:306-313

7. Dhingra R, Sullivan LM, Fox CS, Wang TJ, D'Agostino RB, Sr., Gaziano JM, Vasan RS: Relations of serum phosphorus and calcium levels to the incidence of cardiovascular disease in the community. Arch Intern Med 2007, 167:879-885

8. Tonelli M, Sacks F, Pfeffer M, Gao Z, Curhan G: Relation between serum phosphate level and cardiovascular event rate in people with coronary disease. Circulation 2005, 112:2627-2633

9. Eckstein J, Savic S, Eugster T, Pargger H, Gurke L, Pechula M Steiger J, Mayr M: Extensive calcifications induced by hyperphosphataemia caused by phosphate-based enema in a patient after kidney transplantation. Nephrol Dial Transplant 2006, 21:2013-2016 
10. Beloosesky Y, Grinblat J, Weiss A, Grosman B, Gafter U, Chagnac A: Electrolyte disorders following oral sodium phosphate administration for bowel cleansing in elderly patients. Arch Intern Med 2003, 163:803-808

11. Desmeules S, Bergeron MJ, Isenring P: Acute phosphate nephropathy and renal failure. N Engl J Med 2003, 349:1006-1007

12. Grossman RA, Hamilton RW, Morse BM, Penn AS, Goldberg M: Nontraumatic rhabdomyolysis and acute renal failure. $\mathrm{N}$ Engl J Med 1974, 291:807-811

13. Markowitz GS, Nasr SH, Klein P, Anderson H, Stack JI, Alterman L, Price B, Radhakrishnan J, D'Agati VD: Renal failure due to acute nephrocalcinosis following oral sodium phosphate bowel cleansing. Hum Pathol 2004, 35:675-684

14. Markowitz GS, Stokes MB, Radhakrishnan J, D'Agati VD: Acute phosphate nephropathy following oral sodium phosphate bowel purgative an underrecognized cause of chronic renal failure. J Am Soc Nephrol 2005, 16:3389-3396

15. O'Connor LR, Klein KL, Bethune JE: Hyperphosphatemia in lactic acidosis. N Engl J Med 1977, 297:707-709

16. Markowitz GS, Perazella MA: Acute phosphate nephropathy. Kidney Int 2009, 76:1027-1034

17. Ori Y, Herman M, Tobar A, Chernin G, Gafter U, Chagnac A, Izhak $\mathrm{OB}$, Korzets A: Acute phosphate nephropathy-an emerging threat. Am J Med Sci 2008, 336:309-314

18. Brunelli SM, Lewis JD, Gupta M, Latif SM, Weiner MG, Feldman HI: Risk of kidney injury following oral phosphosoda bowel preparations J Am Soc Nephrol 2007, 18:3199-3205

19. Hurst FP, Bohen EM, Osgard EM, Oliver DK, Das NP, Gao SW, Abbott $\mathrm{KC}$ : Association of oral sodium phosphate purgative use with acute kidney injury. J Am Soc Nephrol 2007, 18:3192-3198

20. Rosenkranz AR, Mendrick DL, Cotran RS, Mayadas TN: P-selectin deficiency exacerbates experimental glomerulonephritis: a protective role for endothelial P-selectin in inflammation. J Clin Invest 1999, 103:649-659

21. Levy JC, Matthews DR, Hermans MP: Correct homeostasis mode assessment (HOMA) evaluation uses the computer program. Diabetes Care 1998, 21:2191-2192

22. Matthews DR, Hosker JP, Rudenski AS, Naylor BA, Treacher DF, Turner RC: Homeostasis model assessment: insulin resistance and beta-cell function from fasting plasma glucose and insulin concentrations in man. Diabetologia 1985, 28:412-419

23. von Kossa J: Ueber die im Organismus kuenstlich erzeugbaren Verkalkungen. Beitr Pathol Anat 1901, 29:163-202

24. Sahn DJ, DeMaria A, Kisslo J, Weyman A: Recommendations regarding quantitation in M-mode echocardiography: results of a survey of echocardiographic measurements. Circulation 1978, 58:1072-1083
25. Eller P, Eller K, Wolf AM, Reinstadler SJ, Tagwerker A, Patsch JR, Mayer G, Rosenkranz AR: Atorvastatin attenuates murine anti-glomerular basement membrane glomerulonephritis. Kidney Int 2010, 77: $428-435$

26. El-Abbadi MM, Pai AS, Leaf EM, Yang HY, Bartley BA, Quan KK, Ingalls CM, Liao HW, Giachelli CM: Phosphate feeding induces arterial medial calcification in uremic mice: role of serum phosphorus, fibroblast growth factor-23, and osteopontin. Kidney Int 2009, 75: 1297-1307

27. Aasebo W, Scott H, Ganss R: Kidney biopsies taken before and after oral sodium phosphate bowel cleansing. Nephrol Dial Transplant 2007, 22:920-922

28. Beyea A, Block C, Schned A: Acute phosphate nephropathy following oral sodium phosphate solution to cleanse the bowel for colonoscopy. Am J Kidney Dis 2007, 50:151-154

29. Connor A, Sykes L, Roberts IS, Weston CE: Acute phosphate nephropathy after sodium phosphate preparations. BMJ 2008, 337: a182

30. Gonlusen G, Akgun H, Ertan A, Olivero J, Truong LD: Renal failure and nephrocalcinosis associated with oral sodium phosphate bowel cleansing: clinical patterns and renal biopsy findings. Arch Pathol Lab Med 2006, 130:101-106

31. Manley P, Somerfield J, Simpson I, Barber A, Zwi J: Bilateral uraemic optic neuritis complicating acute nephrocalcinosis. Nephrol Dial Transplant 2006, 21:2957-2958

32. Rocuts AK, Waikar SS, Alexander MP, Rennke HG, Singh AK: Acute phosphate nephropathy. Kidney Int 2009, 75:987-991

33. Steinman TI, Samir AE, Cornell LD: Case records of the Massachusetts General Hospital: case 27-2008: a 64-year-old man with abdominal pain, nausea, and an elevated level of serum creatinine. N Engl J Med 2008, 359:951-960

34. Gallimore B, Gagnon RF, Richards GK: Role of an intraperitoneal catheter implant in the pathogenesis of experimental Staphylococcus epidermidis peritoneal infection in renal failure mice. Am J Nephrol 1988, 8:334-343

35. Chau H, El-Maadawy S, McKee MD, Tenenhouse HS: Renal calcification in mice homozygous for the disrupted type Ila Na/Pi cotransporter gene Npt2. J Bone Miner Res 2003, 18:644-657

36. Tonelli M, Pannu N, Manns B: Oral phosphate binders in patients with kidney failure. N Engl J Med 2010, 362:1312-1324

37. Zaritsky JJ, Salusky IB: Ironing out the phosphorus problem. Kidney Int 2010, 77:845-847

38. Block GA, Brillhart SL, Persky MS, Am A, Slade AJ: Efficacy and safety of SBR759, a new iron-based phosphate binder. Kidney Int 2010, 77:897-903 